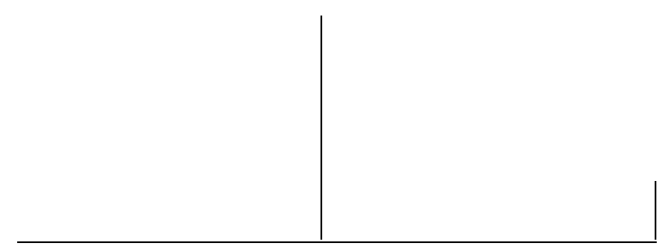

Rev. Latinoam. Psicopat. Fund., X, 1, 549-553

\title{
Sobre o desejo. Segundo tratado da Segunda parte do De l'usage des passions*
}

\author{
J. F. Senault
}

\begin{abstract}
Sobre a natureza, as propriedades e efeitos do desejo
Como o Bem é o único objeto do Amor, ele de forma alguma assume novas formas sem obrigar a Paixão a adotar novos usos. Ela depende tão completamente dele, que muda de nome e de ofício todas as vezes que ele muda de condição. Quando ele está presente, e revela todas as suas belezas, ela nada no prazer. Quando ele corre algum perigo, ela fica tomada pelo medo. Quando ele é atacado pelos inimigos, ela toma das armas, e se encoleriza para defendê-lo. Quando ele se afasta, ela se aflige, e se deixa devorar pela dor. Quando ele se ausenta, ela se consome em anseios e dá forças a seus desejos de ir buscar um objeto cuja distância faz nascer todos os seus desprazeres. Pois o desejo nada mais é que o movimento da alma em direção de um bem que ela já ama e que ainda não possui. Ela se apaga para se unir a ele. Ela procura deixar seu corpo e se separar de si mesma para se juntar ao que procura. Ela esquece seus prazeres, para pensar apenas no que ama. Ela se esforça para vencer a Natureza e a Fortuna, e tornar presente, contra a vontade, o bem ausente que ela deseja.
\end{abstract}

* Tradução de Monica Seincman, Revisão Técnica de Paulo José Carvalho da Silva. 


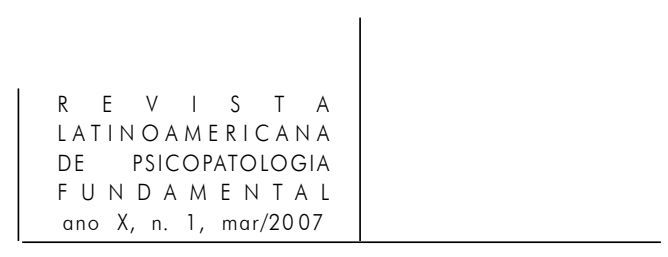

Desta definição é fácil observar as propriedades do Desejo, das quais a primeira é a inquietude, que não sofre por a alma que a concebeu ter podido degustar um verdadeiro contentamento, pois ela está em um estado violento e combate com o corpo que anima, para se unir ao objeto que ama. A Natureza a retém em um e o Amor a leva ao outro. Ela está dividida entre estas duas Potências soberanas, e experimenta um tormento que não é de forma alguma menos rigoroso do que a morte. Também vimos homens que, para se entregarem a ela, condenaram-se de bom grado a suplícios terríveis, e acreditaram que todos os remédios eram doces que curavam de uma doença tão lastimável. O exílio é sem dúvida uma das mais cruéis penas que a Justiça inventou para castigar os culpados. Ele nos separa de tudo que amamos, e parece ser uma longa morte, que nos deixa um pouco de vida para nos tornar mais miseráveis. No entanto, ele encontrou para si uma mãe que preferia sofrer o rigor deste tormento do que a violência do Desejo, e que quis acompanhar seu filho em seu banimento, para não ser condenada a lamentar sua ausência e desejar seu retorno. Também a Natureza, que bem viu que o Desejo era um suplício, fez nascer a Esperança para suavizá-lo. Pois enquanto nós estamos sobre a terra, não temos anseio algum cuja realização nosso espírito não prometa. Há somente Inferno onde estes dois movimentos de nossa alma são divididos, e onde a Justiça divina condena seus inimigos a formar desejos sem esperanças, e definhar por uma felicidade que jamais podem possuir. Eles suspiram pelo Soberano bem, e algum ódio que tenham concebido contra o Deus que os pune não faz com que deixem de amá-lo naturalmente, desejando sua alegria, apesar de não lhes ser permitido ter esperança. Este desejo é a causa de todos os seus suplícios e deste langor, que é um tormento mais insuportável que o ardor das chamas, que a companhia dos Demônios, e que a eternidade de sua prisão. Se eles pudessem ficar sem desejos, não teriam dores. E todas estas outras penas que surpreendem as almas vulgares, lhes pareceriam suportáveis, se não fossem condenados a desejar uma felicidade que não poderiam esperar.

Mas não é apenas nos Infernos que esta paixão é cruel. Ela aflige todos os homens sobre a terra. E, assim como serve à Justiça divina como um meio para castigar os criminosos, ela serve à Misericórdia como um santo artifício para influenciar os inocentes, pois a bondade de Deus os faz serem consumidos em desejos. Eles sentem uma inquietude que apenas pode acabar com sua vida. Eles se esforçam para se afastar de seus corpos. Eles chamam a morte em seu socorro, e dizem com o Apóstolo: "Eu desejo morrer para estar com Jesus Cristo". A Justiça também emprega os desejos para se vingar dos pecadores e, por uma conduta tão severa quanto razoável, os abandona a esta paixão para atormentá-los. Eles somente desejam a fim de se afligir, e sua alma forma anseios 


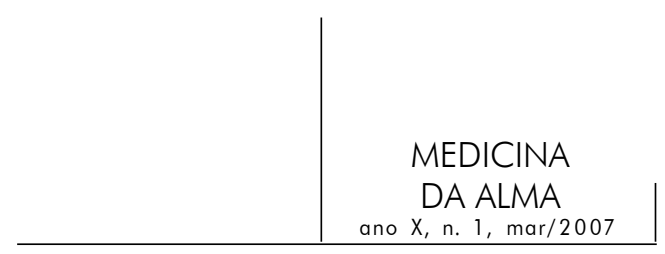

desregrados, que não sendo seguidos de efeitos, os deixam em um langor que dura tanto quanto sua vida. Enfim, a Teologia, reconhecendo que esta paixão é a causa de todas as nossas infelicidades, acreditou que não podia nos descrever melhor a felicidade do que nos dizendo que ela era o fim de todos os desejos. A Filosofia disse que ela é o fim de nossos males, e o começo de nosso bem, que ela nos faz esquecer nossas misérias pela doçura de seus prazeres. Mas a Teologia, que sabe bem que os desejos são os mais violentos suplícios de que sofremos aqui embaixo, contentou-se em dizer que a felicidade era seu repouso e que nós começaríamos a ser felizes quando cessássemos de desejar. É preciso também confessar que o desejo se liga a todas as outras Paixões de nossa alma, dando-lhes ou armas para combater ou forças para nos afligir, pois aquelas que são mais tempestuosas em nossos corações estariam mortas ou languescentes, se não estivessem animadas pelo desejo. O Amor é cruel somente porque deseja a presença daquele que ele ama. O Ódio arranha nossas entranhas apenas por desejar a vingança. A Ambição é deplorável apenas porque deseja as honras. A Avareza atormenta os avarentos apenas para adoecer pelas riquezas. E todas as Paixões são insuportáveis apenas porque são acompanhadas pelo desejo, que, como um mal contagioso, se espalha em todos as afecções de nossa alma, para nos tornar miseráveis.

Se ele é tão cruel, não é menos vergonhoso, e somos obrigados a confessar que é uma prova de nossa fraqueza e de nossa indigência. Pois só podemos recorrer aos anseios quando a potência nos falta, só fazemos nossos desejos aparecerem quando não podemos realizar. Eles são marcas de nosso amor, eles dizem aos Reis da Terra que a sua vontade é maior que seu poder e que querem muitas coisas que não podem executar. Eu bem sei que os desejos os animam às vezes nestas altas empreitadas, em que a dificuldade está sempre misturada com a glória. Eu bem sei que eles excitam suas coragens e que nela produzem este nobre ardor, sem o qual não se empreende e não se executa nada de generoso. Mas eles lhes ensinam também que há apenas o Deus único, que podendo tudo o que quer, de forma alguma tem desejos inúteis, e que somente ele pode tornar, quando bem lhe parecer, todos os seus desejos em realizações. Ele quer antes as coisas que não deseja e conclui antes os acontecimentos que não deseja, mas nos Príncipes com frequiência a impotência impede a execução de seus desejos. Eles são obrigados a ter anseios e usar o socorro do Céu, quando o da terra lhes falta. O pobre Alexandre, vendo morrer seu caro Eféstion, não lhe podia testemunhar seu Amor senão por seus Desejos. Aquele, que distribuía as coroas dos Reis que ele subjugou e que fazia de escravos Soberanos, não podia restituir a saúde a seu favorito. Os votos que ele oferecia ao Céu por sua cura eram tanto provas de sua fraqueza quanto de sua dor, e comunicavam a toda a terra que os anseios dos Príncipes são testemunhos de sua impotência. 


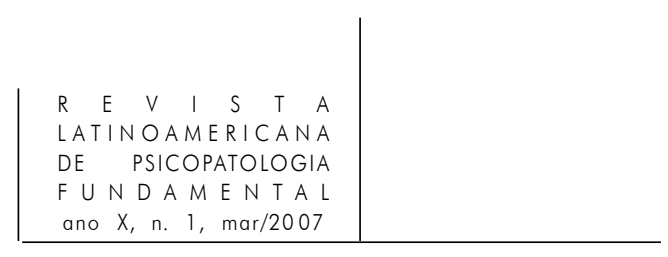

Eles são também em todos os homens marcas públicas de uma pobreza escondida, pois qualquer alma que deseja é necessitada, ela sai de si mesma para procurar em outrem o que lhe falta. Ela revela sua miséria, fazendo aparecer seus anseios, e diz para todo mundo que a felicidade que possui é somente aparente, pois não satisfaz todos os seus desejos. É por isso que o grande Tertuliano expressou dignamente a Natureza desta Paixão, quando disse que é a glória da coisa desejada e a vergonha daquele que a deseja, pois é preciso que uma coisa seja amável para acender nossos desejos. É preciso que ela tenha encantos que nos atraiam e perfeições que nos prendam, mas, certamente, é também preciso que a vontade que a anseia seja indigente e que ela sofra com as necessidades que a obrigam procurar o remédio. O desejo, pois, é a honra da Beleza, e a vergonha dos impudicos. O Desejo é a glória das Riquezas, e a infâmia dos Avaros. O Desejo é o louvor das Dignidades e a censura dos Ambiciosos, e todas as vezes que os Príncipes concebem esta Paixão em suas almas, eles nos fazem saber que sua fortuna tem mais brilho do que verdade, que ela não oferece todos os contentamentos que promete, já que são obrigados a descer de seus tronos, a sair de seus Palácios e procurar por vergonhosas buscas um bem estranho, que apenas encontram em sua pessoa. Também o mais alto louvor que oferece a Deus a santa Escritura é o que nos informa que ele é suficiente para si mesmo e que, possuindo todas as coisas na imensidão de sua Essência, ele não é obrigado a ter anseios, nem a sair de seu repouso para procurar seu contentamento em suas criaturas. $\mathrm{O}$ mundo não contribui em nada para sua grandeza, quando o nada ocupa o lugar do universo e não existem Anjos nem homens para o conhecer e para o amar. Sua felicidade era igualmente completa e todos os louvores que nós agora lhe oferecemos, nada somam à sua glória. Quando lhe imolamos vítimas, quando fazemos ressoar a terra ao som de seus louvores, quando queimamos Incensos sobre os Altares e enriquecemos seus Templos com o despojo de nossas casas, somos obrigados a protestar que todos os nossos presentes lhe são inúteis, que ele nos dá a graça de os aceitar e que nós nada oferecemos para sua Grandeza, que não recebemos sua liberalidade. O Desejo é, pois, uma marca de indigência, e qualquer criatura que tem anseios declara sua pobreza.

Mas para não desonrá-la completamente, é preciso confessar que esta Paixão também é uma prova de nossa dignidade, pois se estende sobre todas as coisas e pretende algum direito sobre tudo o que pode entrar em nossa imaginação. Ela vai procurar os efeitos no seio de suas causas. Ela se persuade de que pode aspirar tudo o que se pode conceber e que pode colocar, em nome de suas riquezas, todos os bens que ainda não possui. Tudo o que é possível a lisonjeia. Ela tem um alcance tão grande, que abraça todas as Promessas da Fortuna e 


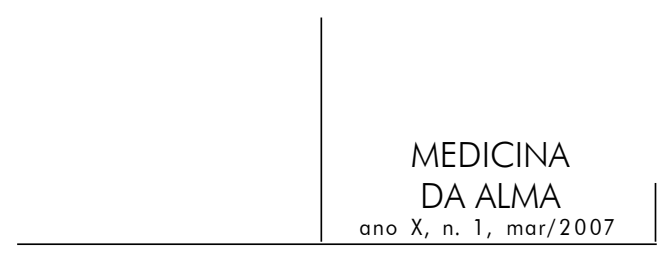

nada acontece aos mais felizes homens do mundo, que não a faça crer poder esperar algum tipo de Justiça, porque um Padre da Igreja disse que os Apóstolos, não abandonando nada, abandonaram muito, pois renunciaram a seus desejos. E que, ao se desfazerem de uma Paixão, que em sua extrema pobreza lhes dava direito sobre todas as riquezas, eles podiam se vangloriar de tudo ter abandonado por Jesus Cristo. Pois o coração do homem tem uma capacidade infinita que pode apenas ser preenchida pelo Soberano bem. Ele está sempre vazio até que possua aquele que o formou. Todos os outros bens o esfaimam e não podem satisfazê-lo. Eles irritam seus desejos e não os apaziguam. Daí não podermos delimitar que o fim de um é o nascimento do outro e nós corremos de objeto em objeto para encontrar aquele do qual os outros não passam de sombras.

Daí nascem todos os desejos desregrados que corroem o coração dos maiores Monarcas. Daí procede a Ambição de Alexandre, que achava a terra pequena demais e que se aborrecia com o fato de suas conquistas estarem limitadas pelo mundo. Daí deriva a Avareza de Crasso, que se estimava pobre, apesar de ser o mais rico dos Romanos e que passava por Desertos terríveis para ir fazer a guerra contra um Povo, cujas únicas riquezas faziam todos os crimes. Estas desordens não têm nenhuma outra fonte que não a capacidade de nosso coração e a infinidade de nossos desejos que, seguindo o bem que os solicita e nada encontrando que os satisfaça, procuram sempre novos e jamais se prescrevem limites. Pois, ainda que nosso espírito não tenha luz suficiente para conhecer a suprema verdade em toda a sua extensão e que nossa vontade não tenha força suficiente para amar o Soberano bem o quanto deve ser, um e outro não deixam de ter uma capacidade infinita, a qual todas as coisas da terra não podem preencher. Uma verdade natural por mais elevada que seja não serve para o nosso espírito senão como um degrau para subir mais alto, e uma bondade criada, por mais rara que possa ser, faz apenas nosso coração se ampliar e dilatar nossa vontade de torná-la capaz de uma mais excelente. Assim nossos desejos mudam perpetuamente de objetos, eles desprezam aqueles que estimaram e, passando sempre avante, sentem que no fim nada os pode deter senão aquilo que os pode satisfazer. Destas três propriedade que explicamos, é fácil observar os efeitos que os desejos produzem em nós ou fora de nós, pois ao separarem a alma do corpo, causam todos estes êxtases e todas estas alegrias atribuídos ao excesso do Amor. Por nascerem da indigência, obrigam-nos a pedir e, por uma seqüência necessária, nos tornam inoportunos aos nossos amigos e por suporem um abismo em nosso coração, não é preciso se surpreender se tudo o que se lhes concede não os pode preencher e se, ao terem perseguido tantos objetos diferentes, eles se cansam de correr e procuram seu repouso no Soberano Bem, que é o fim de todos os Desejos legítimos. 